\title{
Geotechnical and Geophysical Studies for Wind Farms in Earthquake Prone Areas
}

\author{
Ferhat Ozcep ${ }^{1}$, Mehmet Guzel ${ }^{2}$ and Savas Karabulut ${ }^{1}$ \\ ${ }^{1}$ Istanbul University \\ ${ }^{2}$ MES Yeraltı Araştırma, Adana \\ Turkey
}

\section{Introduction}

As Redlinger et al (2002) point out, since antiquity; people have used technology to transform the power of the wind into useful mechanical energy. Wind energy is accepted one of the world's oldest forms of mechanic energy. The re-emergence of the wind as a significant source of the world's energy must rank as one of the significant developments of the late 20th century (Manwell et al, 2009).

Across the Earth's surface, wind is in horizontal motion. Wind power is produced by differences in air pressure between two regions. Wind is a product of solar energy like most other forms of energy in use today. Wind is a clean, abundant, and renewable energy resource that can be tapped to produce electricity. Wind site assessments include: (1) high electricity rates, (2) rebates or tax credits from utilities or governments, (3) a good wind resource, and (4) a long-term perspective (Chiras, 2010).

Procurement costs for critical components and subsystems are given in Table 1 . The critical components of Wind Turbines include blades, rotor shaft, nacelle, gear box, generator, and pitch control unit. The tower, site foundation, and miscellaneous electrical and mechanical accessories are characterized as subsystem elements. As you can see in Table 1, medium percent cost of site and foundation is 17.3. For this reason, soil investigation should carefully be carried out for the wind energy systems.

\section{Soil investigation procedures for wind energy systems}

Site investigation is part of the design process (Day, 2006). A foundation is defined as that part of the structure that supports the weight of the structure and transmits the load to underlying soil or rock. The purpose of the site investigation is to obtain the following (Tomlinson, 1995):

- Knowledge of the general topography of the site as it affects foundation design and construction, e.g., surface configuration, adjacent property, the presence of watercourses, ponds, hedges, trees, rock outcrops, etc., and the available access for construction vehicles and materials.

- The location of buried utilities such as electric power and telephone cables, water mains, and sewers. 
- The general geology of the area, with particular reference to the main geologic formations underlying the site and the possibility of subsidence from mineral extraction or other causes.

- The previous history and use of the site, including information on any defects or failures of existing or former buildings attributable to foundation conditions.

- Any special features such as the possibility of earthquakes or climate factors such as flooding, seasonal swelling and shrinkage, permafrost, and soil erosion.

- The availability and quality of local construction materials such as concrete aggregates, building and road stone, and water for construction purposes.

- For maritime or river structures, information on tidal ranges and river levels, velocity of tidal and river currents, and other hydrographic and meteorological data.

- A detailed record of the soil and rock strata and groundwater conditions within the zones affected by foundation bearing pressures and construction operations, or of any deeper strata affecting the site conditions in any way.

- Results of laboratory tests on soil and rock samples appropriate to the particular foundation design or construction problems.

- Results of chemical analyses on soil or groundwater to determine possible deleterious effects of foundation structures.

\begin{tabular}{|c|c|c|}
\hline Component & Percent of Total System Cost & $\begin{array}{c}\text { Medium Percent } \\
\text { Cost }\end{array}$ \\
\hline Rotor blades & 3 to 11.2 & 7.1 \\
\hline Gear box and generator & 13.4 to 35.4 & 24.4 \\
\hline Hub, nacelle and shaft & 5.3 to 3.5 & 18.4 \\
\hline Control system elements & 4.2 to 10.2 & 7.2 \\
\hline Tower & 5.3 to 31.1 & 18.2 \\
\hline Site and foundation & 8.4 to 26.2 & 17.3 \\
\hline Miscellaneous engineering & 3.2 to 11.4 & 7.3 \\
\hline
\end{tabular}

Table 1. Estimated Procurement Costs of Critical Components of Wind Turbines (Jha, 2010)

An approach for organizing a site investigation assessment is given In Table 2. Geotechnical site characterization requires a full 3-D representation of stratigraphy (including variability), estimates of geotechnical parameters and hydrogeological conditions and properties (Campanella, 2008).

The natural materials that constitute the earth's crust are rather arbitrarily divided by engineers into two categories, soil and rock. Soil is a natural aggregate of mineral grains that can be separated by such gentle mechanical means as agitation in water (Terzaghi and Peck, 1967). in a dynamic sense, seismic waves generated at the source of an earthquake propagate through different soil horizons until they reach the surface at a specific site. The travel paths of these seismic waves in the uppermost soil layers strongly affect their characteristics, producing different effects on earthquake motion at the ground surface. Local amplification caused by surficial soft soils is a significant factor in destructive earthquake motion. Frequently, site conditions determine the types of damage from moderate to large earthquakes (Bard, 1998; Pitikalis, 2004; Safak, 2001). 


\begin{tabular}{|c|c|c|c|c|c|}
\hline Site & \multirow[b]{2}{*}{ Administration } & \multirow[b]{2}{*}{ Preliminary } & \multirow[b]{2}{*}{ Feasibility } & \multicolumn{2}{|c|}{ Records and reports } \\
\hline \multirow[t]{2}{*}{ Planning } & & & & $\begin{array}{l}\text { Priliminary } \\
\text { Assesment }\end{array}$ & $\begin{array}{c}\text { Planned } \\
\text { Strategy and } \\
\text { programme } \\
\text { contingency } \\
\text { proposals }\end{array}$ \\
\hline & Desk Study & & & & \\
\hline \multirow{9}{*}{ Design } & Reconnainces & Main study & $\begin{array}{l}\text { Geotechnical } \\
\text { Evaluation }\end{array}$ & & \\
\hline & Constraints & & Profiling & & \\
\hline & $\begin{array}{l}\text { Procurement } \\
\text { Method }\end{array}$ & & $\begin{array}{l}\text { Material and } \\
\text { Groundwater } \\
\text { characteristics }\end{array}$ & & \\
\hline & & & & $\begin{array}{c}\text { Field data } \\
\text { Presentation }\end{array}$ & \\
\hline & $\begin{array}{l}\text { Foundation } \\
\text { Design } \\
\text { Assesment }\end{array}$ & $\begin{array}{l}\text { Specialised } \\
\text { Studies }\end{array}$ & Geophysics & & as per code \\
\hline & $\begin{array}{l}\text { Development of } \\
\text { Investigation } \\
\text { Strategy }\end{array}$ & & $\begin{array}{l}\text { Dynamic and } \\
\text { static probes }\end{array}$ & $\begin{array}{c}\text { Factual / } \\
\text { Intraprative } \\
\text { Report }\end{array}$ & \\
\hline & $\begin{array}{l}\text { Programme of } \\
\text { Site Activity }\end{array}$ & & Presurmenters & & \\
\hline & & & Dilatometers & & \\
\hline & & & Hydrographic & & \\
\hline
\end{tabular}

Table 2. Planning and Design of Site Investigations (Head, 1986)

The design of a foundation, an earth dam, or a retaining wall cannot be made intelligently unless the designer has at least a reasonably accurate conception of the physical properties of the soils involved. The field and laboratory investigations required to obtain this essential information constitute soil exploration (Ozcep, 2010). There are several soil problems at local and regional scale related to the civil engineering structures (Ozcep, F. and Zarif, H., 2009; Ozcep, et al 2009;2010a, b, c Korkmaz and Ozcep, 2010).

\subsection{Subsurface exploration}

In order to obtain the detailed record of the soil/rock media and groundwater conditions at the site, subsurface exploration is usually required. Types of subsurface exploration are the borings, test pits, and trenches. Many different types of samplers are used to retrieve soil and rock specimens from the borings. Common examples show three types of samplers, the "California Sampler," Shelby tube sampler, and Standard Penetration Test (SPT) sampler (Day, 2006). 


\subsection{Field testing}

There are many different types of tests that can be performed at the time of drilling and/or project site. The three types of field tests are most commonly used geotechnical practice: Standard Penetration Test (SPT), Cone Penetration Test (CPT) and Geophysical Tests.

\subsubsection{Standard Penetration Test (SPT)}

The Standard Penetration Test (SPT) consists of driving a thick-walled sampler into a sand deposit. The measured SPT $N$ value can be influenced by many testing factors and soil conditions. For example, gravel-size particles increase the driving resistance (hence increased $N$ value) by becoming stuck in the SPT sampler tip or barrel. Another factor that could influence the measured SPT $N$ value is groundwater (Day, 2006).

\subsubsection{Cone Penetration Test (CPT)}

The idea for the Cone Penetration Test (CPT) is similar to that for the Standard Penetration Test, except that instead of a thickwalled sampler being driven into the soil, a steel cone is pushed into the soil. There are many different types of cone penetration devices, such as the mechanical cone, mechanical-friction cone, electric cone, seismic and piezocone (Day, 2006).

\subsubsection{Geophysical tests}

Broadly speaking, geophysical surveys are used in one of two roles. Firstly, to aid a rapid and economical choice between a number of alternative sites for a proposed project, prior to detailed design investigation and, secondly, as part of the detailed site assessment at the chosen location. Geophysical methods also have a major role to play in resource assessment and the determination of engineering parameters. The recently issued British Code of Practice for Site Investigations (BS 5930:1999) sets out four primary applications for engineering geophysical methods:

1. Geological investigations: geophysical methods have a major role to play in mapping stratigraphy, determining the thickness of superficial deposits and the depth to engineering rockhead, establishing weathering profiles, and the study of particular erosional and structural features (e.g. location of buried channels, faults, dykes, etc.).

2. Resources assessment: location of aquifers and determination of water quality; exploration of sand and gravel deposits, and rock for aggregate; identification of clay deposits.

3. Determination of engineering parameters: such as dynamic elastic moduli needed to solve many soil-structure interaction problems; soil corrosivity for pipeline protection studies; rock rippability and rock quality.

4. Detection of voids and buried artefacts: e.g. mineshafts, natural cavities, old foundations, pipelines, wrecks at sea etc.

\subsubsection{Seismic tests}

Seismic tests are conventionally classified into borehole (invasive) and surface (noninvasive) methods. They are based on the propagation of body waves [compressional $(\mathrm{P})$ and/or shear (S)] and surface waves [Rayleigh (R)], which are associated to very small strain levels (i.e. less than $0.001 \%$ ) (Woods, 1978). Seismic surveys provide two types of information on the rock or soil mass (McCann et al, 1997): 
- Seismic refraction and reflection surveys may be carried out to investigate the continuity of geological strata over the site and the location of major discontinuities, such as fault zones.

- From measurements of the compressional and shear wave velocities it is possible to determine the dynamic elastic moduli of the soil/rock mass and estimate its degree of fracturing

\subsubsection{Electrical resistivity measurements}

Electrical depth soundings are effective in horizontal stratified media, since the spatial distribution of the electrical current in the ground and, hence, the depth of investigation depends on the configuration of the array and the spacing of the electrodes. When using a Standard Wenner or Schlumberger array the depth of investigation increases with the current electrode spacing and this gives rise to an electrical resistivity depth section which can be related to the geological structure beneath the survey line (McCann et al ,1997).

\subsection{Laboratory testing}

In addition to document review, subsurface exploration and filed tests, laboratory testing is an important part of the site investigation. The laboratory testing usually begins once the subsurface exploration and tests is complete. The first step in the laboratory testing is to log in all of the materials (soil, rock, or groundwater) recovered from the subsurface exploration. Then the engineer prepares a laboratory testing program, which basically consists of assigning specific laboratory tests for the soil specimens (Day, 2006).

\subsubsection{Index tests}

Index tests are the most basic types of laboratory tests performed on soil samples.Index tests include the water content (also known as moisture content), specific gravity tests, unit weight determinations, and particle size distributions and Atterberg limits, which are used to classify the soil (Day, 2006).

\subsubsection{Soil classification tests}

The purpose of soil classification is to provide the geotechnical engineer with a way to predict the behavior of the soil for engineering projects (Day, 2006).

\subsubsection{Shear strength tests}

The shear strength of a soil is a basic geotechnical parameter and is required for the analysis of foundations, earthwork, and slope stability problems (Day, 2006).

\section{On geophysical and geotechnical parameters based on site-specific soil investigations}

A geotechnical study (i.e site-specific soil investigation) must be carried out for all "Wind Farm" projects. All geotechnical designs must be based on a sufficient number of borings, geophysical and geotechnical tests. At each foundation of Wind Energy System (WES), integrated use of one borehole, geophysical and geotechnical tests is strongly recommended. If some sites vary in soil features, different number of suitable boreholes is made on the edges of the proposed foundation, based on discussions and meetings with the 
geotechnical/geophysical/geological engineers according to the local soil characteristics. Related to the static and dynamic loads, the parameters and problems such as foundation bearing capacity, settlement, stiffness, possible degradation, soil liquefaction and amplification must be investigated in detail.

There are an interaction between tower stiffness, foundation stiffness and soil stiffness, and these are formed total stiffness of Wind Energy System (WES).

Engineer requires to calculate static and dynamic coefficients of compressibility by using the soil dynamic properties such as:

- $\cdot \mathrm{Gd}\left[\mathrm{MN} / \mathrm{m}^{2}\right]$ - dynamic shear modulus

- $\cdot \rho\left[\mathrm{kg} / \mathrm{m}^{3}\right]$ - soil density $\left[\mathrm{t} / \mathrm{m}^{3}\right]$; the moist density of natural soil, in case of water saturation including the water filling the pore volume, is introduced as density

- $\cdot[v]$ - Poisson's ratio.

The dynamic properties of the soil material are obtained by using geophysical testing. These geophysical (spectral analysis of surface waves, seismic CPT, down-hole, seismic cross-hole seismic refraction and reflection, suspension logging, steady-state vibration) tests are based on the low-strain tests. It does not represent the non-linear or non-elastic stress strain behavior of soil materials. These studies must be performed by a qualified geophysical engineer or geophysicists.

The sampling intervals of SPT (standard penetration test) should not be in excess of 1 to $1.5 \mathrm{~m}$. CPT (cone penetration testing tests) is recommended, because they continuously give the soil properties with depth. All soil layers that influence foundation of project must be investigated.

\subsection{Soil settlement criteria}

The settlement analysis is taken in to consideration as immediate elastic settlements (primer) and time-dependent consolidation (secondary) settlements. For the tower, a foundation inclination has $3 \mathrm{~mm} / \mathrm{m}$ permissible value after settlement. In the case of the dynamic analysis of the machine, it should be considered additional rotations of the tower base during power production.

The completely vertical long-term settlement due only to the gravity weights is less than $20 \mathrm{~mm}$ in any case. This situation should be verified by Geotechnical Engineer.

The safety factor for failure of the soil material (soil shear failure) should be min.3.

\subsection{Stiffness requirements}

Wind Energy Structures (WES) are subject to strong dynamic stresses. Dynamic system properties, i.e. in particular the natural frequencies of the overall system consisting of the foundation, tower, machine and rotor, are therefore of particular importance for load determination.

The foundation structures in interaction with the foundation soil, is modeled by approximation using equivalent springs (torsion and linear springs). Figure 1 provides a comparison between wind turbine generator system and the simplified analysis model. Each model parameter is dependent on soil properties.

Over its design lifetime, the foundation of wind energy structure must provide the minimum levels of stiffness required in the foundation loads. The rotation of the foundation (and resulting maximum permissible vertical settlement of the foundation soil) under the operational forces is limited to be less than the values of rotational stiffness. 


\subsection{Ground water and dewatering requirements}

The two properties of a rock or soil which are most important in controlling the behaviour of subsurface water are (a) how much water the rock or soil can hold in empty spaces within it, and (b) how easily and rapidly the water can flow through and out of it (McLean and Gribble, 1985).

For all required foundation excavation depths, ground water table level shall be considered. Excavation dewatering due to high ground water levels, presence of water bearing strata or impermeable materials (rock, clays, etc.) must be considered as required by specific site conditions.
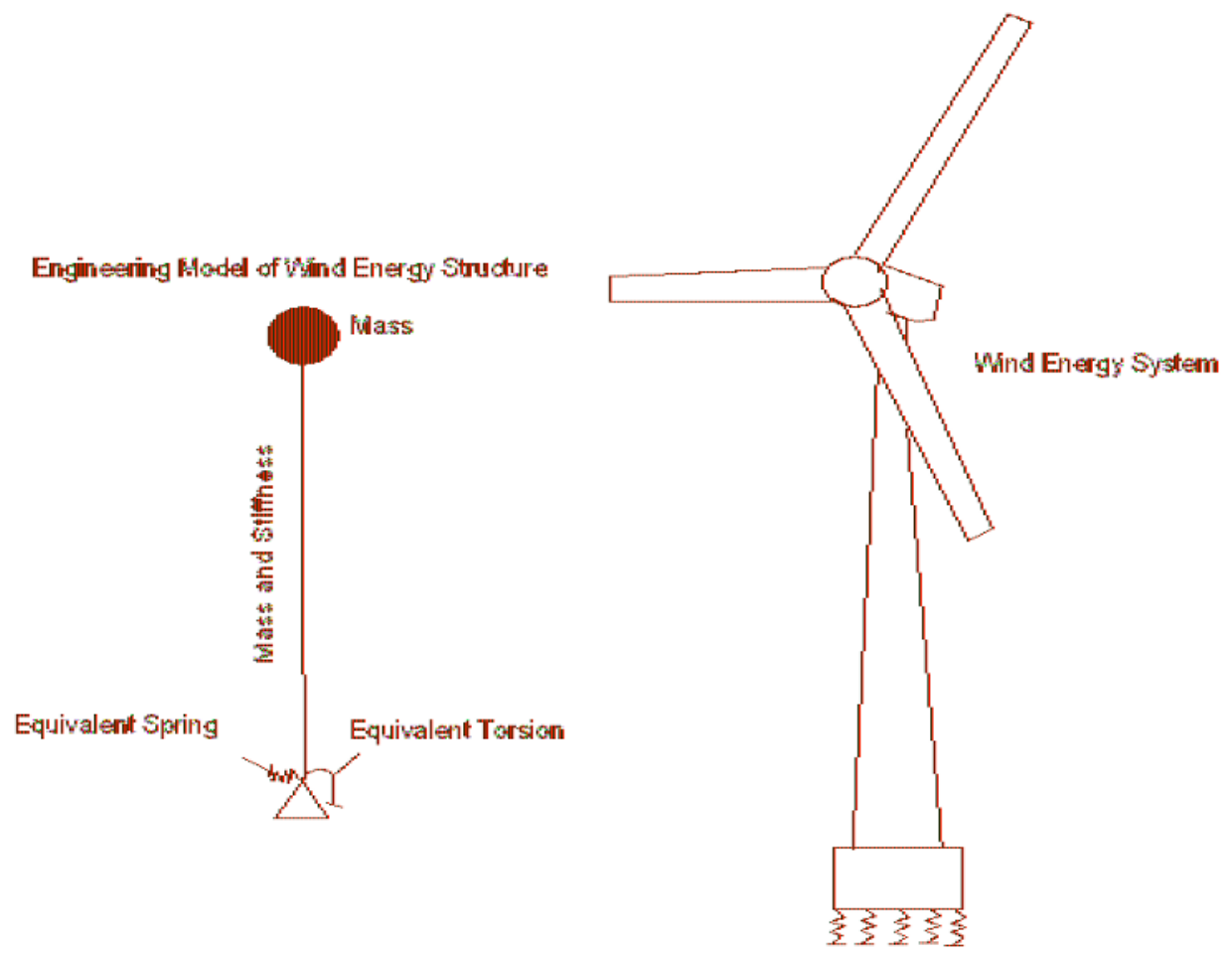

Fig. 1. Wind energy system and the analysis model.

\subsection{Design of wind energy systems to withstand earthquakes}

Earthquakes impose additional loads on to wind energy systems. The earthquake loading is of short duration, cyclic and involves motion in the horizontal and vertical directions. Wind energy system (The tower and foundation) need to withstand earthquake forces. Earthquakes can affect these systems by causing any of the following:

- Soil settlement and cracking

- Liquefaction or loss of shear strength due to increase in pore pressures induced by the earthquake in systems and its foundations;

- Differential movements on faults passing through the foundation 
- Soil amplification

- Soil bearing capacity reduction

The potential for such problems depend on:

- The seismicity of the project area

- $\quad$ Soil / rock materials and topographic conditions at the site;

- $\quad$ The type and detailed construction of the wind energy system;

- The groundwater level in the wind energy system at the time of the earthquake.

As shown in Figure 2, the focal distance from an earthquake to a point on the earth's surface is the three dimensional slant distance from the focus to the point, while the epicentral distance is the horizontal distance from the epicentre to the point. Possible earthquake magnitude and these factors (epicentral distance, focal dept and focal distance) are related to the ground motion level at the project site.

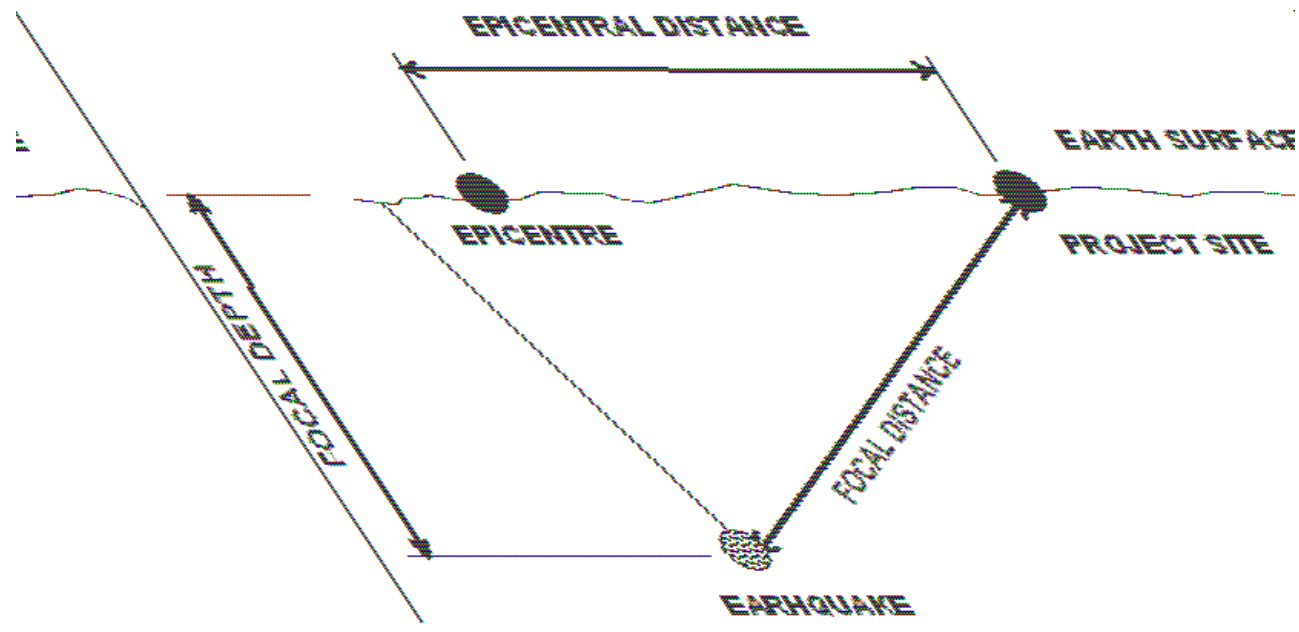

Fig. 2. The focal distance from an earthquake to a point on the earth's surface.

\subsubsection{Evaluation of seismic hazard}

For a given project site, a seismic hazard evaluation is to identify the seismic sources on which future earthquakes are likely to occur, to estimate the magnitudes and frequency of occurrence of earthquakes on each seismic source, and to identify the distance and orientation of each seismic source in relation to the site. When the deterministic approach is used to characterize the ground motions for project site, then a scenario earthquake is usually used to represent the seismic hazard, and its frequency of occurrence does not directly influence the level of the hazard. In the other hand, when the probabilistic approach is used, then the ground motions from a large number of possible earthquakes are considered and their frequencies of occurrence are key parameters in the analysis (Somerville and Moriwaki, 2003).

\subsubsection{Probabilistic approach}

Given the uncertainty in the timing, location, and magnitude of future earthquakes, and the uncertainty in the level of the ground motion that a specified earthquake will generate at a 
particular site, it is often appropriate to use a probabilistic approach to characterizing the ground motion that a given site will experience in the future (Somerville and Moriwaki, 2003).

The probabilistic estimation of ground motion requires the following seismicity information about the surrounding area:

- The rate of occurrence and magnitude of earthquakes;

- The relative proportion of small to large events (b value);

- The maximum earthquake size expected

- The spatial distribution of earthquake epicenters including delineation of faults

\subsubsection{Seismic hazard from known active faults: deterministic approach}

This method is used where faults in the vicinity of the wind farm can be identified. The procedure will usually include:

- Identification of major faults within the vicinity of the wind farm.

- Assessment of whether the faults are active or potentially active, by consideration of whether modern (including small) earthquakes have been recorded along the fault.

- Assessment of the maximum earthquake magnitude on each identified fault. This will usually be determined by considering the length and/or area of the fault and the type of fault. The likely focal depth and, hence, focal distance are also estimated.

\subsubsection{Selection of design seismic loading}

There are two ways of selecting the design seismic loading: deterministic and probabilistic. Whichever approach is taken, the bedrock ground motions need to be adjusted where appropriate for amplification (or de-amplification) effects. The probabilistic approach to seismic hazard characterization is very compatible with current trends in earthquake engineering and the development of building codes. Examples of conceptual frameworks are given in Figure 3.

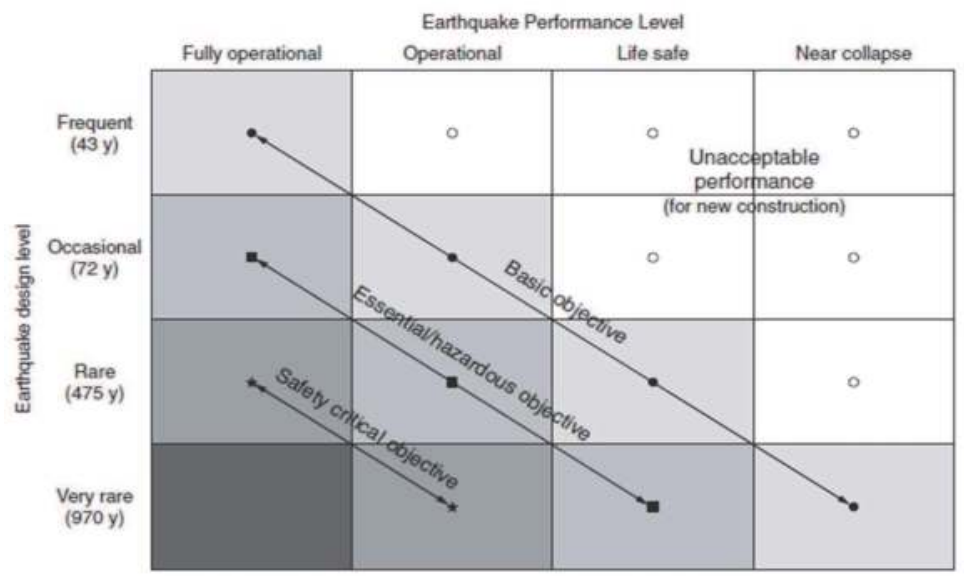

Fig. 3. Seismic performance objectives for buildings (SEAOC, 1996), showing increasingly undesirable performance characteristics from left to right on the horizontal axis and increasing level of ground motion from top to bottom on the vertical axis. Performance objectives for three categories of structures are shown by the diagonal lines (Hall et all, 1995). 


\section{Bahce (Osmaniye, Turkey) case for wind energy systems (from Ozcep et al, 2010)}

\subsection{Introduction}

Geological observations, geophysical measurements, soil explorations, in-situ tests and laboratory tests have been performed over the study area. This survey has been realized in order to be able to decide basic systems in an element, which is one of the turbine locations of Wind Power Plant (135 MW) that is planned to be constructed in Bahçe county of Osmaniye province and in order to be used as a basis for the superstructure loads to be transferred to the soil in detail. Presentation of the location map of the site with several cities and main seismogenetic fault described in Figure 4.1a.

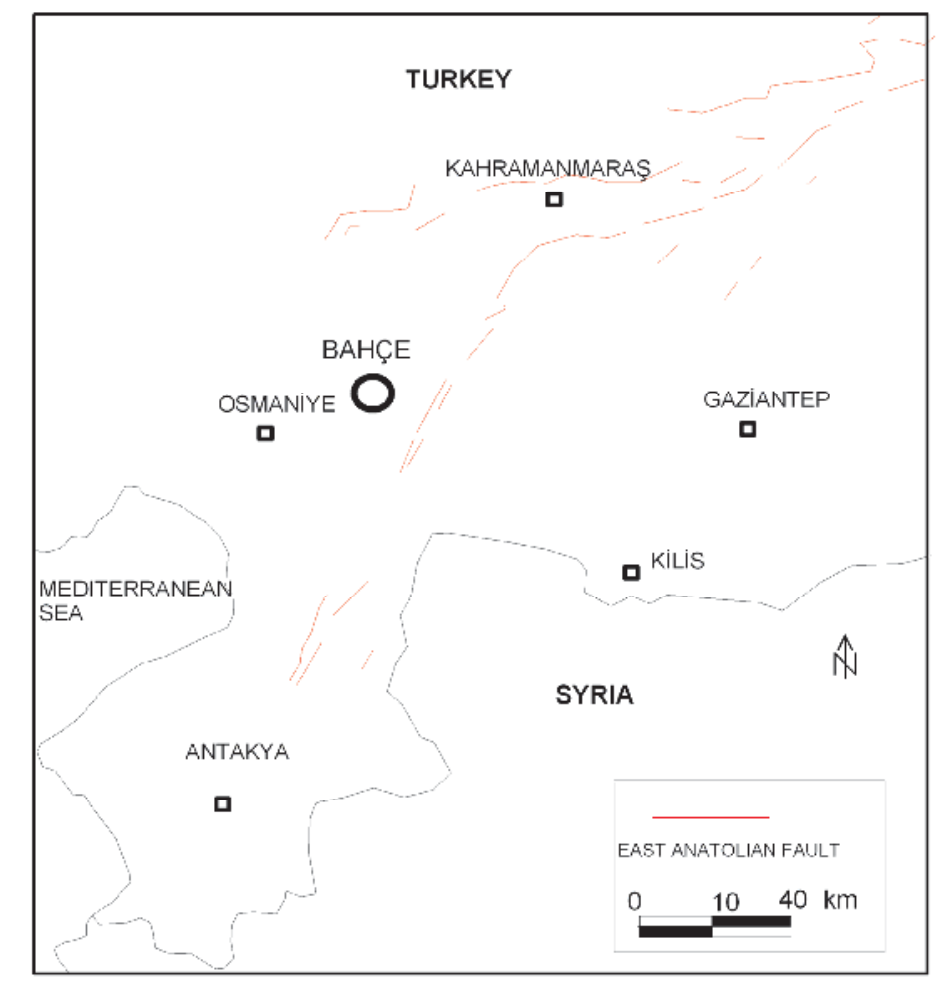

Fig. 4.1a. Presentation of the location map of the site with several cities and main seismogenetic fault

\subsubsection{Geological framework}

From the structural point of view; Amanos Mountain is located over the intersections of the tectonic zones or within the impact area of these zones which are well known world wide. At Nur Mountain, characteristic folding and faulting properties are being observed. Overturned, overthrust and canted folding in different scales are observed. Spring water 
and percolating water are becoming dense in the western part and are being observed over discontinuity zones depending on the structural geology. These springs and percolations have resulted important amount of decomposition over the main rock. The engineering properties of the geological units differ from one region to another depending on the structure and hydro-geology and types of rocks. Study area is near the Eastern Anatolia Fault zone which is strike slip fault zone. Eastern Anatolia Fault has not been formed of only one single fault but has been formed of as a complex fault system or zone.

\subsubsection{Seismic hazard analysis of region}

Seismic hazard analyses aim at assessing the probability that the ground motion parameter at a site due to the earthquakes from potential seismic sources will exceed a certain value in a given time period (Erdik et al, 1999, Erdik and Durukal, 2004). Deterministic and Probabilistic approaches are used in developing ground motions in professional practice. The deterministic approach is based on selected scenario earthquakes and specified ground motion probability level, which is usually median ground motion or median-plus-one standard deviation. The probabilistic approach encompasses all possible earthquake scenarios, all ground motion probabilities and computes the probability of the ground motion to be experienced at the site exceeding a certain value in a given time period. Empirical attenuation relationships are generally employed in the quantification of seismic hazard in either deterministic or probabilistic approaches (Seismic Microzonation for Municipalities: Manual, 2004).

For deterministic seismic hazard analysis, two fault model are selected namely A (fault rapture is $50 \mathrm{~km}$ ) and B faults (fault rapture is $245 \mathrm{~km}$ ) within east Anatolian fault Zone (Table 4.1.1a and 4.1.1b).

\begin{tabular}{|c|c|c|}
\hline Researcher & M (magnitude) & Magnitude Type \\
\hline Ambraseys and Zatopek (1969) & $\mathrm{M}=(0,881 \mathrm{LOG}(\mathrm{L}))+5,62$ & $\mathrm{Ms}$ \\
\hline Douglas and Ryall (1975) & $\mathrm{M}=(\mathrm{LOG}(\mathrm{L})+4,673) / 0,9$ & $\mathrm{Ms}$ \\
\hline Ezen (1981) & $\mathrm{M}=(\mathrm{LOG}(\mathrm{L})+2,19) / 0,577$ & $\mathrm{Ms}$ \\
\hline Toksöz et al (1979) & $\mathrm{M}=(\mathrm{LOG}(\mathrm{L})+3,62) / 0,78$ & $\mathrm{Ms}$ \\
\hline Wells and Coppersmith (1994) & $\mathrm{M}=5,16+(1,12 \mathrm{LOG}(\mathrm{L}))$ & $\mathrm{Mw}$ \\
\hline
\end{tabular}

Table 4.1.1a. Equations for Rapture Length and Magnitude Estimations 


\begin{tabular}{|c|c|c|}
\hline Researchers & $\begin{array}{c}\text { M (magnitude) } \\
\text { Estimations For A } \\
\text { Model }\end{array}$ & $\begin{array}{c}\text { M (magnitude) } \\
\text { Estimations For B Model }\end{array}$ \\
\hline Ambraseys and Zatopek (1969) & 7,1 & 7,5 \\
\hline Douglas and Ryall (1975) & 7,1 & 7,6 \\
\hline Ezen (1981) & 6,7 & 7,5 \\
\hline Toksöz et al (1978) & 6,8 & 7,4 \\
\hline Wells and Coppersmith (1994) & 7,1 & 7,6 \\
\hline
\end{tabular}

Table 4.1.1b. Selected two fault model (A : fault rapture length is $50 \mathrm{~km}$ ) and B : fault rapture length is $245 \mathrm{~km}$ ) within East Anatolian Fault Zone.

Earthquake ranges for analysis were taken from 4.5 to 7.5 about $100 \mathrm{~km}$ radius (Table 1c) Gutenberg-Richter recurrence relationships was determined as

$$
\log (\mathrm{N})=\mathrm{a}-\mathrm{b} M
$$

Earthquake occurrence probability were given by using

$$
R m=1-e^{-(N(M) \cdot D)}
$$

Where $\mathrm{Rm}=$ Risk value (\%); D, duration; N(M) for M magnitude (1) equation value.

\begin{tabular}{|c|c|c|c|}
\hline $\begin{array}{c}\text { Magnitude } \\
\text { Ranges }\end{array}$ & $4.5 \leq \mathrm{M}<5.0$ & $5.0 \leq \mathrm{M}<5.5$ & $5.5 \leq \mathrm{M}<6.0$ \\
\hline $\begin{array}{c}\text { Number of } \\
\text { Earthquakes }\end{array}$ & 34 & 9 & 6 \\
\hline
\end{tabular}

Table 4.1.1c. Earthquake Magnitude ranges in study area about $100 \mathrm{~km}$ radius. Data are obtained by BU KOERI, compiled by Kalafat et al, 2007)

Attenuation relationship was defined by several attenuation models (see Table 4.1.2a). From a set of attenuation relationships, the average acceleration values of the cities was calculated with exceeding probability of $10 \%$ in 50 years by using several attenuation models as shown in Table 4.1.2b and c. 


\begin{tabular}{|c|c|}
\hline $\begin{array}{c}\mathrm{a}=\text { Acceleration Value }\left(\mathrm{cm} / \mathrm{sn}^{2}\right) \\
\text { PHA = Pick Horizontal Acceleration } \\
\mathrm{M}=\text { Earthquake Magnitude } \\
\mathrm{D}=\text { Epicentral Distance }(\mathrm{km}) \\
\text { R = Radial Distance from Focal depth }(\mathrm{km})\end{array}$ & Researchers \\
\hline$. a=1300 e^{0.67 M}(R+25)^{-1.6}$ & Donovan (1973) \\
\hline$. \log a=3.09+0.347 M-2 \log (R+25)$ & Oliviera (1974) \\
\hline $\begin{array}{c}\log (a / g)=-1.02+0.249 M-\log R-0.00255 R+0.26 \\
\text { where; } R=\left(D^{2}+7.3^{2}\right)^{0.5}\end{array}$ & Joyner and Boore (1981) \\
\hline 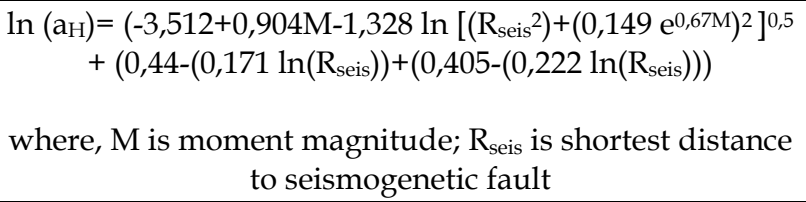 & Campbel (1997) \\
\hline
\end{tabular}

Table 4.1.2a. Used Acceleration Attenuation Relationships in this Study

Figure 4.1.1b. shows active fault zones, earthquakes in historical and instrumental periods near study area. Seismic hazard analysis for the region are carried out on the earthquakes bigger than 4.5 for 106 years of period.

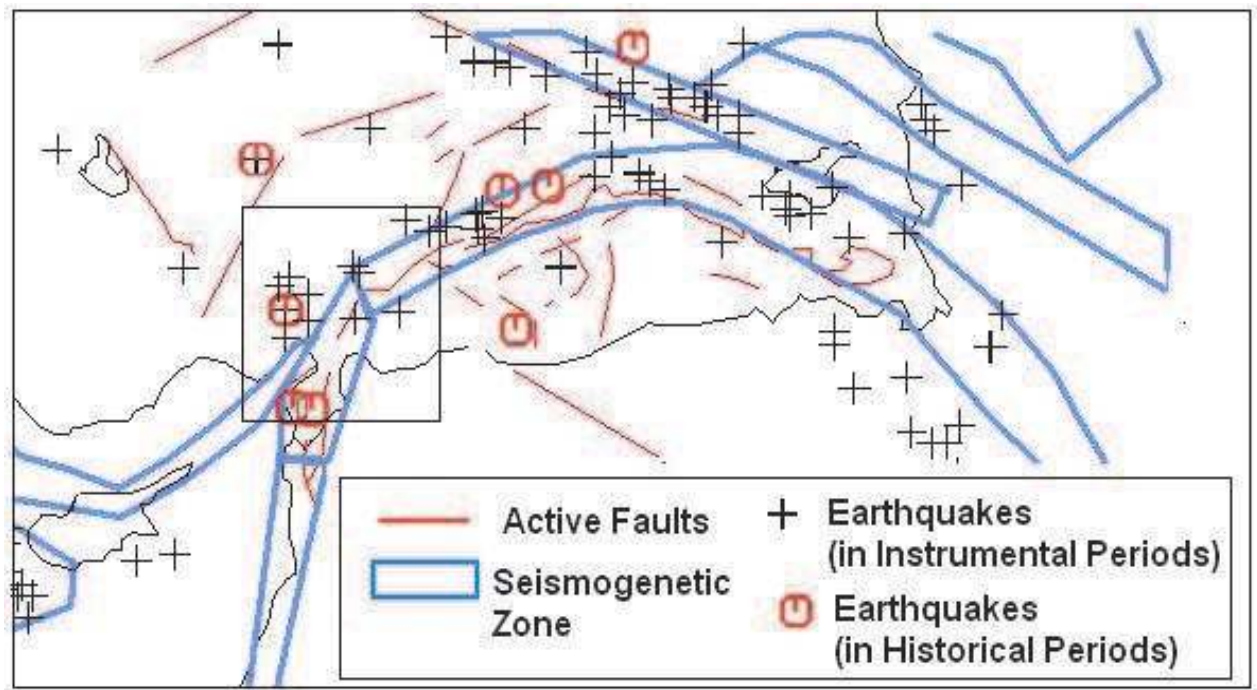

Fig. 4.1.1b. Active fault zones, earthquakes (M larger than 5.5) in Historical and Instrumental time intervals around the Study Area (a quadrangle) (map is redrawn by Erdik et al, 1999)

Poisson probabilistic approach is applied to earthquake data. Table $2 b$. shows earthquake probability (\%) for selected year by Poison distribution in the study area, and Table 2c shows ground motion level at the site exceeding (\%10) in a given time period (50 years). 


\begin{tabular}{|c|c|c|c|c|c|}
\cline { 2 - 6 } \multicolumn{1}{c|}{} & \multicolumn{4}{c|}{ Probability (\%) For D (Year) } & \\
\hline Magnitude & 10 & 50 & 75 & 100 & $\begin{array}{c} \\
\text { Average } \\
\text { Return Period } \\
\text { (Years) }\end{array}$ \\
\hline 5 & 90,5 & 100,0 & 100,0 & 100,0 & 4 \\
\hline 5,5 & 56,1 & 98,4 & 99,8 & 100,0 & 12 \\
\hline 6 & 25,0 & 76,3 & 88,5 & 94,4 & 34 \\
\hline 6,5 & 9,6 & 39,6 & 53,1 & 63,5 & 98 \\
\hline 7 & 3,5 & 16,2 & 23,3 & 29,7 & 281 \\
\hline 7,5 & 1,2 & 6,0 & 8,8 & 11,6 & 802 \\
\hline
\end{tabular}

Table 4.1.2b. Earthquake Occurrence Probability (\%) for D (Year) by Poison distribution in the Study Area

\begin{tabular}{|c|c|c|c|c|}
\hline & D (year) & $\begin{array}{c}\text { Probability of } \\
\text { Exceedence }(\%)\end{array}$ & M (magnitude) & \\
\hline \multirow[t]{2}{*}{ for } & 50 & 10 & 7,2 & \\
\hline & $\begin{array}{c}\Delta, \text { Epicentral } \\
\text { Distance }(\mathrm{km})\end{array}$ & $\begin{array}{c}\text { H, Focal depth } \\
(\mathrm{km})\end{array}$ & & \\
\hline \multirow[t]{2}{*}{ for } & 25 & 15 & & \\
\hline & $\begin{array}{l}\text { Donavan } \\
(1973)\end{array}$ & Oliviera (1974) & $\begin{array}{l}\text { Joyner and } \\
\text { Boore (1981) }\end{array}$ & Campbell (1997) \\
\hline $\begin{array}{c}\text { Estimated a } \\
(\mathrm{g})\end{array}$ & 0,26 & 0,19 & 0,59 & 0,45 \\
\hline
\end{tabular}

Table 4.1.2c. Ground motion probabilities show the probability of the ground motion to be experienced at the site exceeding $(10 \%)$ in a given time period (50 years).

\subsection{Site investigations}

\subsubsection{Test pits}

Information has been obtained from observation purpose superficial excavations and in the laboratory evaluations, drilling samples have been used.

\subsubsection{Drilling wells}

As a result of the observations and analysis performed over the survey area and near environment, it has been planned and realized 2 drilling (SK-1 on the middle of the base, SK-2 at the edge of the base) wells with 30 meter over the area at which the construction base will be settled (Table $4.3 \mathrm{a})$. 


\begin{tabular}{|c|c|c|}
\hline Borhole & Depth $\mathbf{( m )}$ & LITHOLOGY \\
\hline SK-1 & $0,00-7,50$ & $\begin{array}{c}\text { gray colored, faulted and fractured, melted cellular from } \\
\text { place to place limestone with rarely calcite filled faults, } \\
\text { calcite grained, with brown colored decomposition } \\
\text { surfaces }\end{array}$ \\
\hline SK-2 & $7,50-30,00$ & $\begin{array}{c}\text { gray colored, melted cellular limestone with brown } \\
\text { colored decomposition surfaces, calcite grained from } \\
\text { place to place, fractured, medium sometimes thick } \\
\text { layered }\end{array}$ \\
\hline $0,00-7,50$ & $\begin{array}{c}\text { gray colored, faulted and fractured, melted cellular from } \\
\text { place to place limestone with rarely calcite filled faults, } \\
\text { calcite grained, with brown colored decomposition } \\
\text { surfaces }\end{array}$ \\
\hline $7,50-30,00$ & $\begin{array}{c}\text { gray colored, melted cellular limestone with brown } \\
\text { colored decomposition surfaces, calcite grained from } \\
\text { place to place, fractured, medium sometimes thick } \\
\text { layered }\end{array}$ \\
\hline
\end{tabular}

Table 4.3a. Lithology according to the drilling results

\subsubsection{Surface and ground water}

There is no ground or superficial water danger which could affect the basic systems of the turbine planned to be constructed over the survey area. However, the contact and interaction of the superficial water and standing water which can accumulate during and after the construction of the foundations of the turbine as a result of the seasonal precipitations should be prevented.

\subsubsection{Field tests}

\subsubsection{SPT tests and core evaluations}

Since the survey area is formed by rock units even from the surface (not suitable for SPT experiment), core samples obtained from drillings have been evaluated.

\subsubsection{Geophysical tests}

\section{A. Seismic tests}

In the seismic studies which have been performed over the soil of the survey area, mainly seismic refraction method which is used in direct and reverse shooting has been applied. Seismic measurements have been made by measuring both longitudinal (or compressional), $\mathrm{Vp}$ and also transversal (or shear), Vs wave velocities. Vp has been measured in order to determine the underground structural locations in horizontal and lateral directions, Vs has been measured in order to know the elastic properties. Geophone intervals in seismic measurements have been selected as $2 \mathrm{~m}$. Table $3 \mathrm{~b}$ shows geotechnical parameters obtained by seismic tests. 


\begin{tabular}{|c|c|c|c|c|c|c|c|c|}
\hline 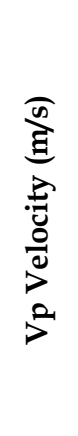 & 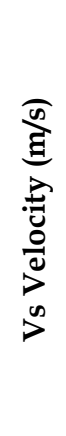 & $\sum_{i}^{\infty}$ & 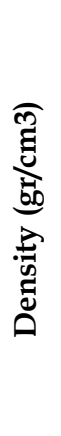 & 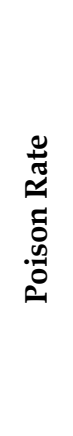 & 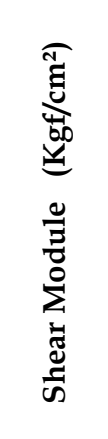 & 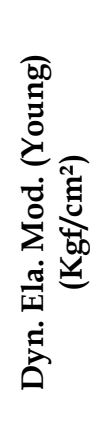 & 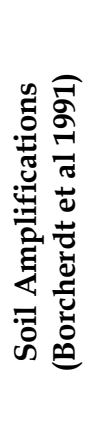 & 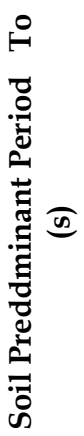 \\
\hline 1811 & 834 & 2,17 & 2,1 & 0,37 & 14.922 & 40.750 & 0,7 & 0,16 \\
\hline 1835 & 791 & 2,32 & 2,1 & 0,39 & 13.419 & 37.195 & 0,8 & 0,17 \\
\hline
\end{tabular}

Table 4.3.b. Average geotechnical parameters obtained by seismic tests

\section{B. Electric resistivity applications}

In the resistivity studies which are made in order to clarify the lithological structure of the soil of the survey area, SAS (signal Average System) resistivity measurement system has been used. Soil resistivity is being changed depending on the grain size, water content, porosity and permeability. At the survey area, the variation of the apparent resistivity with the depth has been analyzed by applying Vertical Electric Drilling, in the Schlumberger permutation technique with $2 \mathrm{AB} / 2=40 \mathrm{~m}$ expansion and so the structural disorder, depth, lithology, thickness of layers, underground water capacity, corrosion degree which is especially important in the structuring have been analyzed by using the resistivity differences (Table 4.3c).

\begin{tabular}{|c|c|}
\hline Resistivity Value & Corrosion Degree \\
\hline Resistivity $<10 \mathrm{ohm} . \mathrm{m}$ & More Corrosive \\
\hline $10<$ Resistivity $<30 \mathrm{ohm} . \mathrm{m}$ & Corrosive \\
\hline $30<$ Resistivity $<100 \mathrm{ohm} . \mathrm{m}$ & Medium Corrosive \\
\hline 100 ohm.m $<$ Resistivity & Not Corrosive \\
\hline
\end{tabular}

Table 4.3c. Soil Resistivity and Corrosion Level According to Turkish Standards

The results of the measurements obtained in survey area and the soil curves formed by the apparent resistivity values which are varied according to the depth have been evaluated manually and by using computer. The resistivity values of the survey area are as follows (Table 4.3.d). 


\begin{tabular}{|c|c|c|}
\hline \multicolumn{3}{|c|}{ Resistivity Values of the units in survey area } \\
\hline Unit & Thickness(m) & Resistivity (Ohm.m) \\
\hline First Layer & $7-8$ & $345-360$ Ohm.m \\
\hline Second Layer & 50 & $1083-1217$ Ohm.m \\
\hline
\end{tabular}

Table 4.3d. Resistivity Values of the units in survey area

\subsection{Laboratory tests and analysis}

\section{Index / Physical Properties of the Soil / Rock}

The tests which are complying with the R.T. Ministry of Public Works norms and TS1900 have been performed over the soil / rock core samples which have been taken from the boreholes that had been drilled during field surveys.

\subsection{Engineering analysis and evaluations}

\subsubsection{Determination of soil -structure relation}

a. Foundation System

Required laboratory studies have been made over the observations, soil excavations, geophysical applications about the mentioned foundation soil which has been analyzed regarding geotechnical perspective and the obtained parameters have been specified in the above sections.

The planned structures (wind towers) are high towers having rigid bearing systems. Raft foundation will be a proper foundation solution for this project since this kind of a foundation will provide safety against differential settlements, will protect the integrity of the bearing system under the earthquake loads and dynamic wind load, as well as static loads.

b. Bearing Capacity

Allowable bearing capacity calculations regarding the related parameters about either soil / rock or structure have been made separately in different approaches by taking into account land data, laboratory experiment results and drilling core observations and Rock Quality Designation (RQD) values. The rock and soil formations of the environment have been taken into account in the selection of the calculation methods. At the soil / rock locations which are not convenient to provide samples proper for the experiments required for the method (especially in rock tri-axial experiment required for the Bell method), values which have been obtained from the other locations of the same unit or the known technical literature values have been taken into account.

c. Settlements

Even it is not expected to occur the Settlements which exceeds the acceptable limits under the load to the soil as a result of the structuring over this soil of which most parts that the structure foundation will be based are clay, silt the Settlements value of the medium which has been calculated according to the elasticity module (dynamic) and Poisson ratio values. Special attention should be given not to place the foundation over the excessive splitted, weak durable or decomposed units except the survey points during the foundation excavation and not to place the foundation over differentiated units. Before the construction 
and after the excavation, and during and after the construction, it is required to protect the foundation area from the superficial waters and rains and adequate discharging system should be designed.

d. Liquefaction

There is no ground water danger in a depth up to 20 meters which can negatively affect the foundation structure over the survey area.

e. Soil Class and Other Parameters

The soil of the survey area is rock formed of faulted, fractured, layered limestone units, Vs shear wave velocity (if the thin layer in the surface is ignored) which has been obtained from the Geophysical - Seismic studies has been measured in between 791-834 m/s. According to the Turkish Earthquake Code, these velocities correspond to Soil Group (A), Local Soil Class (Z1) but since these units are fractured and have frequent discontinuity intervals, it is better to classify them as B group Z2 soil class. A little bit more clarification explaining the difference between both classes is given Table 4.5.1 and 4.5.2. Spectrum characteristic periods which are regarded according to the selected foundation type TA and TB are respectively $\mathbf{0 , 1 0 - 0 , 4 0}(\mathbf{s})$. Soil dominant vibration period has been calculated as $\mathbf{0 , 1 6} \mathbf{~ s e c}$.

\begin{tabular}{|c|c|}
\hline Soil Group & $\begin{array}{c}\text { Shear } \\
\text { Wave } \\
\text { Velocity } \\
(\mathrm{m} / \mathrm{s})\end{array}$ \\
\hline (A) & $>700$ \\
\hline (B) & $400-700$ \\
\hline
\end{tabular}

Table 4.5.2. Soil Groups according to Turkish Earthquake Design Code

\begin{tabular}{|c|c|c|}
\hline $\begin{array}{c}\text { Local Site } \\
\text { Class }\end{array}$ & $\begin{array}{c}\text { Soil Group } \\
\text { according to Table } \\
6 \text { and } \\
\text { Topmost Layer } \\
\text { Thickness (h1 }\end{array}$ & $\begin{array}{c}\text { Spectrum Characteristic } \\
\text { Periods (TA, TB) }\end{array}$ \\
\hline Z1 & $\begin{array}{l}\text { Group (A) soils } \\
\text { Group (B) soils } \\
\text { with h1 } \leq 15 \mathrm{~m}\end{array}$ & Between 0.10 and $0.30 \mathrm{~s}$ \\
\hline $\mathrm{Z2}$ & $\begin{array}{l}\text { Group (B) soils } \\
\text { with h1 }>15 \mathrm{~m} \\
\text { Group (C) soils } \\
\text { with h1 } \leq 15 \mathrm{~m}\end{array}$ & Between 0.15 and $0.40 \mathrm{~s}$ \\
\hline
\end{tabular}

Table 4.5.3. Local Site Class and Spectrum Characteristic Periods ( TA , TB) According To Turkish Earthquake Design Code 


\section{Conclusions and suggestions}

The following results have been obtained after the geological, geophysical, geotechnical studies performed over the area at which the Wind Power Plant turbine (Osmaniye Bahçe) will be constructed;

a. In the performed observational geological surveys; as a result of the laboratory experiments performed over the core drilling applications of which the survey depth is 30 meter, geophysical seismic velocity measurements and electric sounding (resistivity) applications, samples / drilling cores obtained from the soil.

b. It has been found out that there are limestone units which are gray colored, cracked and fractured, melted cellular from place to place, with rarely calcite filled cracks,

c. calcite grained, with brown colored decomposition surfaces up to 7,5 meter and from this depth until 30 meters,

d. it has been found out that there are limestone units which are gray colored, melted cellular, with brown colored decomposition surfaces, calcite grained from place to place, fractured, medium sometimes thick layered.

e. The point load bearing of the ponderous samples of the units are in between $19,83-58,78$ $\mathrm{kg} / \mathrm{cm}^{2}$ values and the uniaxial pressure bearing are in between $125,44-358,64 \mathrm{~kg} / \mathrm{cm}^{2}$ values. Cohesion value against the main rock is $(\mathrm{Si})=6,72 \mathrm{Mpa}$ and internal friction angle is $(\varnothing)=34,80$. These data are obtained by laboratory measurements.

f. Over the survey area, there is no natural disaster risk such as floods, landslides, flows, avalanches, rock fallings are not observed.

g. Over the survey area, there is no underground water which could negatively affect the foundations of the turbine. There is no liquefaction hazard.

h. Even it is not expected to occur the settlements which exceed the acceptable limits under the load to the soil as a result of the structuring over this soil of which most parts that the structure foundation will be based are limestone. The cracked, fractured, decomposed units at the upper parts should be removed gradually and in a controlled manner during the foundation excavation. Special attention should be given not to place the foundation over the excessive splitted, weak durable or decomposed units except the survey points.

It is required to inform the designing company whenever a situation such as undesirable due to the foundation structuring or poor durability, micro faults, etc., is met different than the soil profile described in logs, in order company to get necessary precautions on time and in required locations.

e) Raft (spread) foundation will be a proper foundation solution in order to be on the safe side against cracks and discontinuities, since this kind of a foundation will provide safety against differential settlements, will protect the integrity of the bearing system under the earthquake loads and dynamic wind load, as well as static loads. After the foundation excavations are completed, the upper surface of the foundation soil should be smoothly leveled and the foundation construction (in order to increase the friction) should be started by concreting over the natural soil surface.

\section{References}

Ambraseys, N.N. \& Zapotek, A. (1969). The Mudurnu valley (West Anatolia, Turkey) earthquake of 22 July 1967, Bull. of the Seis. Soc. of Am., 59,2,521-589 p. 
Bard, P.Y. (1998). Microtremor measurements: a tool for site effect estimation? Proceedings Second International Symposium on the Effects of Surface Geology on Seismic MotionESG98, Yokohama, Japan, pp. 1251-1279.

Borcherdt, R.D.; Wentworth, C.M.; Janssen, A.; Fumal, T. \& Gibbs, J. (1991). Methodology for Predictive GIS Mapping of Special Study Zones for Strong Ground Shaking in the San Francisco Bay Region, Proc. Fourth Intern'l. Conf. on Seismic Zonation, Vol.3, pp. 545-552.

BS 5930, (1999). The Code of Practice for Site Investigations, The British Standards Institution.

Campbell, K.W. (1997). Empirical Near-Source Attenuation Relationships for Horizontal and Vertical Components of Peak Ground Acceleration, Peak Ground Velocity, and Pseudo-Absolute Acceleration Response Spectra, Seismological Research Letters, Vol. 68, No. 1, pp. 154-179.

Campanella, R.G. (2008). Geo-environmental site characterization, Geotechnical and Geophysical Site Characterization - Huang \& Mayne (eds), Taylor \& Francis Group, London, ISBN 978-0-415-46936-4

Chiras, D. (2010). Wind Power Basics, New Society Publishers, P.O. Box 189, Gabriola Island, BC v0r 1x0, Canada

Day, R., 2006, Foundation Engineering Handbook, The McGraw-Hill.

Douglas, M.B., Ryall, A. (1975). Return periods for rock acceleration in western Nevada , Bull, of the Seis. Soc. of Am., 65: 1599-1611

Donovan, N.C. (1973). A Statistical Evaluation of Strong Motion Data Including the February 9, 1971 San Fernando Earthquake, World Conference on Earthquake Engineering, V, Rome, Proceedings, v. 2, paper 155., Milano, Italia.

Erdik, M. \& Durukal, E. (2004) Strong Ground Motion in Recent Advances, In: Earthquake Geotechnical Engineering and Microzonation, A. Ansal (ed.) , Kluwer Academic Publishers, Netherlans.

Erdik, M.; Alpay, T.; Biro, Y.; Onur, T.; Sesetyan, K. \& Birgoren, G. (1999). Assessment of earthquake hazard in Turkey and neighboring regions, Annali di Geofisica, Vol. 42, pp. 1125-1138.

Ezen, Ü. (1981). Kuzey Anadolu fay zonunda deprem kaynak parametrelerinin magnitüdle ilişkisi, Deprem Araştırma Enstütüsü Dergisi, No: 31, p. 32, Ankara.

Hall, J.H.; Heaton, T.H.; Halling, M.W. \& Wald, D.J., (1995). Near-Source Ground Motion and its Effects on Flexible Buildings, Earthquake Spectra, Vol. 11.

Head, J.M. (1986). Planning and Design of Site Investigations, In: Site Investigation Practice: Assessing BS 5930, edited by A. B. Hawkins Geological Society, Engineering Geology Special Publication No. 2.

Jha, A.R. (2010). Wind Turbine Technology, CRC Pres.

Joyner, W.B. \& Boore, D.M. (1981). Peak Horizontal Acceleration and Velocity from Strong Motion Records, Including Records from the 1979 Imperial Valley, California, Earthquake, Bull. Seis. Soc. Am., Vol:71, No:6, pp. 2011-2038.

Kalafat, D.; Gunes, Y.; Kara, M.; Deniz, P.; Kekovali, K.; Kuleli, S.; Gulen, L.; Yılmazer, M. \& Ozel, N.M. (2007). A revised and extended earthquake catalog for Turkey since 1900 (M> 4.0), Bogazici University Kandilli Observatory and Earthquake Reaserch Institute, İstanbul.

Oliviera, C.S. (1974). Seismic Risk Analysis, Univ. of California, Berkeley, Report no: EERC 741 
Manwell, J.; McGowan, J. \& Rogers, A. (2009). Wind Energy Explained: Theory, Design, And Application, John Wiley \& Sons Ltd.

McLean, A.C., Gribble, C.D. (1985). Geology For Civil Engineers, Taylor \& Francis.

McCann, D. M., Eddleston, M., Fenning, P. J. \& Reeves, G. M. (eds), 1997, Modern Geophysics in Engineering Geology. Geological Society Engineering Geology Special Publication No. 12, pp. 3-34.

Ozcep, F., Guzel, M., Kepekci, D., Laman, M., Bozdag, S., Cetin, H. \& Akat, A. (2009). Geotechnical and Geophysical Studies for Wind Energy Systems İn EarthquakeProne Areas: Bahce (Osmaniye, Turkey) Case, International Journal of Physical Sciences Vol. 4 (10), pp. 555-561.

Ozcep, F. (2010). SoilEngineering: a Microsofts Excel ${ }^{\circledR}$ Spreadsheet $\odot$ Program for Geotechnical and Geophysical Analysis of Soils, Computers \& Geosciences, Volume 36, Issue 10, October 2010, Pages 1355-1361

Ozcep, F. \& Zarif, H. (2009). Variations Of Soil Liquefaction Safety Factors Depending On Several Design Earthquakes in The City Of Yalova (Turkey), Scientific Research and Essay Vol. 4 (6) pp. 594-604.

Ozcep, F.; Tezel, O. \& Asci, M. (2009). Correlation between Electrical Resistivity and SoilWater Content: Istanbul and Golcuk, International Journal of Physical Sciences, Vol. 4 (6), pp. 362-365.

Ozcep, F.; Yıldırım, E.; Tezel, O.; Asci, M. \& Karabulut, S. (2010a). Correlation between Electrical Resistivity and Soil-Water Content based Artificial Intelligent techniques, International Journal of Physical Sciences, Vol. 5 (1), pp. 047 - 056.

Korkmaz, B. \& Ozcep, F., (2010). Fast and Efficient Use of Geophysical and Geotechnical Data in Urban Microzonation Studies At Small Scales : Using Sisli (Istanbul) As Example, International Journal of Physical Sciences, Vol. 5 (2), pp. 158 - 169.

Ozcep, F.; Karabulut, S.; Korkmaz, B. \& Zarif , H. (2010b). Seismic Microzonation Studies in Sisli / Istanbul (Turkey), Scientific Research and Essay, 4 July 2010; 5(13), pp. 1595 1614.

Ozcep, F.; Erol, E.; Saraçoğlu, F. \& Haliloğlu, M. (2010c). Seismic slope stabilty analysis: Gurpinar (istanbul) as a case history, Scientific Research and Essay, 4 July 2010; 5(13), pp. $1615-1631$.

Pitikalis, G. (2004). Site effects, In: Recent Advances in Earthquake Geotechnical Engineering and Microzonation, A. Ansal (Ed.) Kluwer Academic Publishers, Netherlands, p. 139-197.

Redlinger, R.Y.; Andersen, P.D. \& Morthorst, P.E. (2002). Wind Energy in the 21st Century: Economics, Policy, Technology and the Changing Electricity Industry, PALGRAVE Pub.

Safak, E. (2001). Local site effects and dynamic soil behavior, Soil Dynamics and Earthquake Engineering 21(5), 453-458.

Somerville, P. \& Moriwaki, Y. (2003). Seismic Hazards and Risk Assessment in Engineering Practice, In: International Handbook Of Earthquake And Engineering Seismology, Vol. $81 B$, Edited by William H. K. Lee, Hiroo Kanamori, Paul C. Jennings, and Carl Kisslinger.

Terzaghi, K. \& Peck, R.B. (1967). Soil Mechanics in Engineering Practice, Second Edition, A Wiley International Edition, New York. 321pp.

Toksöz, N.; Nabalek, J. \& Arpat, E. (1978). Source Properties Of The 1976 Earthquake İn East Turkey, Tectonophysics, 49, 3-4, 199-205. 
Tomlinson, M.J., 1995, Foundation Design and Construction, 5th ed., John Wiley \& Sons, Inc., New York.

Wells, D.L. \& Coppersmith, K.J. (1994). New Emprical Relationships amomg magnitude, rapture length, repture width, repture area, and surface displacement, Bull. of the Seis. Soc. of Am., 84, N0: 4, 974-1002.

Woods, R. D. (1978) Measurement of dynamic soil properties, Earthquake Engineering and Soil Dynamics, Pasadena, CA, 1: 91-179 


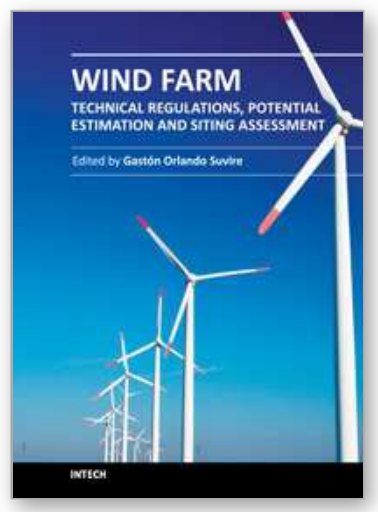

\section{Wind Farm - Technical Regulations, Potential Estimation and Siting Assessment}

Edited by Dr. Gast $\tilde{A}^{3} n$ Orlando Suvire

ISBN 978-953-307-483-2

Hard cover, 234 pages

Publisher InTech

Published online 14, June, 2011

Published in print edition June, 2011

The evolution of wind power generation is being produced with a very high growth rate at world level (around $30 \%$ ). This growth, together with the foreseeable installation of many wind farms in a near future, forces the utilities to evaluate diverse aspects of the integration of wind power generation in the power systems. This book addresses a wide variety of issues regarding the integration of wind farms in power systems. It contains 10 chapters divided into three parts. The first part outlines aspects related to technical regulations and costs of wind farms. In the second part, the potential estimation and the impact on the environment of wind energy project are presented. Finally, the third part covers issues of the siting assessment of wind farms.

\section{How to reference}

In order to correctly reference this scholarly work, feel free to copy and paste the following:

Ferhat Ozcep, Mehmet Guzel and Savas Karabulut (2011). Geotechnical and Geophysical Studies for Wind Farms in Earhquake-Prone Areas, Wind Farm - Technical Regulations, Potential Estimation and Siting Assessment, Dr. GastÃ ${ }^{3 n}$ Orlando Suvire (Ed.), ISBN: 978-953-307-483-2, InTech, Available from: http://www.intechopen.com/books/wind-farm-technical-regulations-potential-estimation-and-sitingassessment/geotechnical-and-geophysical-studies-for-wind-farms-in-earhquake-prone-areas 1

\section{INTECH}

open science | open minds

\section{InTech Europe}

University Campus STeP Ri

Slavka Krautzeka 83/A

51000 Rijeka, Croatia

Phone: +385 (51) 770447

Fax: +385 (51) 686166

www.intechopen.com

\section{InTech China}

Unit 405, Office Block, Hotel Equatorial Shanghai

No.65, Yan An Road (West), Shanghai, 200040, China 中国上海市延安西路65号上海国际贵都大饭店办公楼 405 单元

Phone: $+86-21-62489820$

Fax: +86-21-62489821 
(C) 2011 The Author(s). Licensee IntechOpen. This chapter is distributed under the terms of the Creative Commons Attribution-NonCommercialShareAlike-3.0 License, which permits use, distribution and reproduction for non-commercial purposes, provided the original is properly cited and derivative works building on this content are distributed under the same license. 